\title{
ON THE EROSIVE TRAIL OF A 14TH AND 15TH CENTURY HURRICANE IN CONNECTICUT (USA) SALT MARSHES
}

\author{
O van de Plassche $e^{1,2} \bullet$ A J Wright ${ }^{1} \bullet \mathrm{K}_{\text {van }} \operatorname{der}_{\text {Borg }^{3}} \bullet \mathrm{A} \mathrm{F} \mathrm{M} \mathrm{de} \mathrm{Jong}^{3}$
}

\begin{abstract}
This paper examines if an erosive hiatus found in the peat stratigraphy and marsh-accumulation record from northwest Hammock River Marsh (HRM), Connecticut (CT) can be attributed to a 14th or a 15th century hurricane, each documented by a radiocarbon-dated overwash fan in Succotash Marsh (SM) (Rhode Island) about $90 \mathrm{~km}$ to the east. Given that (i) the best estimate age range for the 15th century overwash deposit in SM (1400-1440 cal AD, $2 \sigma$ ) overlaps entirely with that for first plant growth after erosion at HRM (1390-1450 cal AD, $2 \sigma)$, while the best estimate age range for the 14th century overwash deposit (1290-1410 cal AD, $2 \sigma$ ) overlaps just $10 \mathrm{yr}$, and (ii) interpretation of the available stratigraphic and sedimentary evidence from HRM suggests that a high-energy event offers the simplest explanation for the observed marsh erosion, we conclude that a plausible link exists between the 15th century hurricane and the marsh erosion in HRM. The best estimate age range for the 14th century hurricane appears to overlap for $91 \%$ with the age range for the first plant growth (1290-1400 cal AD, $2 \sigma$ ) following marsh erosion in East River Marsh (CT), located about $12 \mathrm{~km}$ west of HRM. These results imply that erosive boundaries in salt-marsh peat deposits have potential as markers of past hurricane activity.
\end{abstract}

\section{INTRODUCTION}

Salt-marsh deposits along the eastern coast and Gulf Coast of the United States are well known to contain sedimentary records of hurricanes, both as washover deposits behind barriers capped by low dunes, and as thin (mm to $\mathrm{cm}$ ) beds of sand, silt and/or clay along open coast marshes (e.g. Warren and Niering 1993; Nyman et al. 1995; Donnelly et al. 2001a). In contrast, the literature makes no mention of hurricane-related erosion surfaces preserved in the stratigraphy of salt-marsh deposits. In this paper, we present evidence for salt-marsh erosion and assess if it can be attributed to hurricane activity.

Our study site is located in the northwestern part of Hammock River Marsh (HRM), Connecticut, USA (Figure 1), for which van de Plassche et al. (1998) published a marsh-accumulation record spanning the past $1400 \mathrm{yr}$. This record is based on paleomarsh-surface estimates obtained by radiocarbon dating preserved sub-surface parts of marsh grasses (e.g. rhizomes, root bulbs, and subsurface stems) with a known vertical relationship to the marsh surface (i.e. paleomarsh-surface indicators). It shows 2 short ( $<100 \mathrm{yr})$ periods of very high $\left(4-8 \mathrm{~mm}_{\mathrm{yr}}{ }^{-1}\right)$ rates of marsh accumulation during the past $600 \mathrm{yr}$, the first beginning around $1425 \mathrm{cal}$ AD (Figure 2) and the second shortly after $1650 \mathrm{cal} \mathrm{AD}$ (not shown). On the basis of limited core stratigraphic data, it was claimed that each period of rapid marsh accumulation was preceded by erosion. The possibility that this erosion was hurricane-related is suggested by the fact that the onset of the first period of rapid marsh accumulation (around 1425 cal AD) coincides with a geologically documented hurricane which affected Succotash Marsh (SM), Rhode Island (1411-1446 cal AD) (Donnelly et al. 2001a,b) (Figure 2). Furthermore, the approximate onset of the second period of rapid marsh accumulation (shortly after $1650 \mathrm{cal} \mathrm{AD}$ ) follows closely on the historically documented hurricanes of AD 1635 and AD 1638, both of which made landfall in southern New England (Boose et al. 2001).

\section{SALT-MARSH SUB-ENVIRONMENTS}

New England salt marshes show a tripartite vegetation zonation, generally referred to as the low, high, and upper marsh zones (e.g. Niering and Warren 1980; Bertness 1991). The low marsh zone is

\footnotetext{
${ }^{1}$ Faculty of Earth and Life Sciences, Vrije Universiteit, De Boelelaan 1085, 1081 HV Amsterdam, the Netherlands.

${ }^{2}$ Corresponding author. Email: orson.van.de.plassche@falw.vu.nl.

${ }^{3} \mathrm{R}$ J van der Graaff Laboratory, Universiteit Utrecht, P.O. Box 80.000, 3508 TA, the Netherlands.
}

(C) 2004 by the Arizona Board of Regents on behalf of the University of Arizona Proceedings of the 18th International Radiocarbon Conference, edited by N Beavan Athfield and R J Sparks RADIOCARBON, Vol 46, Nr 2, 2004, p 775-784 

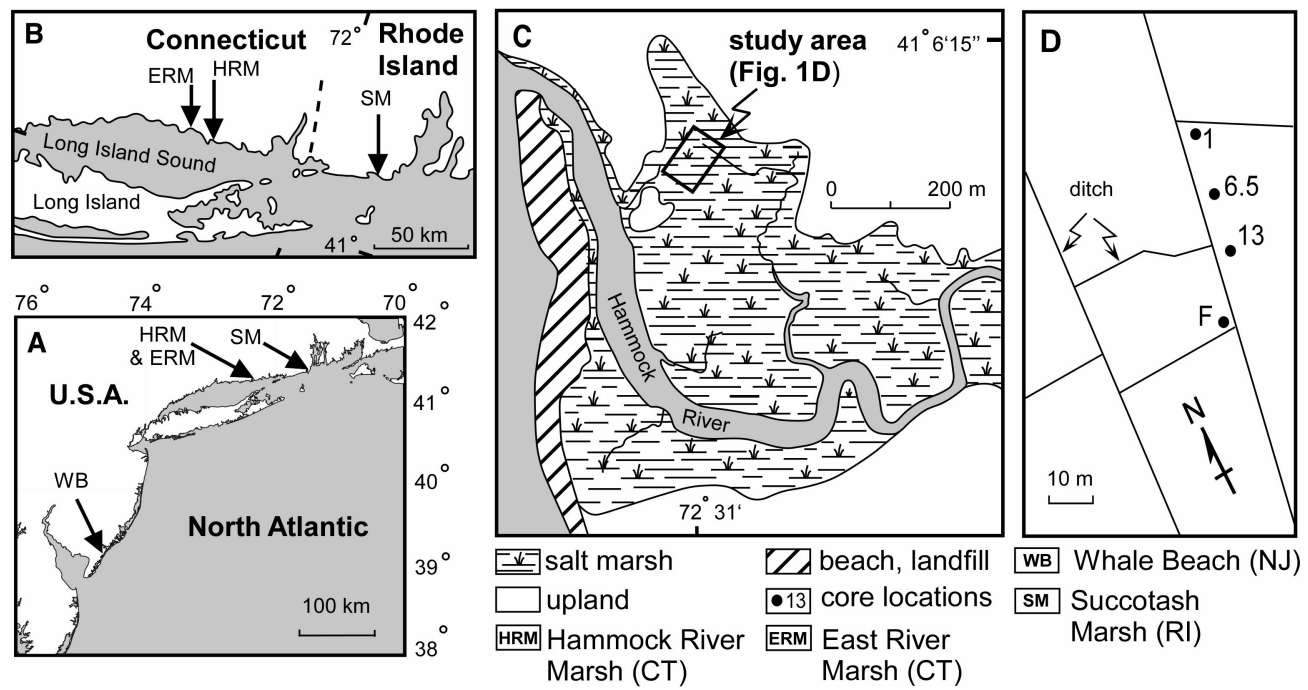

Figure 1 Location of study areas and coring sites mentioned in the text

characterized by pure stands of the tall form of Spartina alterniflora (smooth cordgrass). This plant is the first to colonize tidal flats which have reached an elevation between mean sea level and mean high water of neap tides. Low marsh accumulation rates can be quite high owing to the combination of high flooding frequency and sediment trapping by the vegetation. Once the low marsh has accumulated to around mean high water level, grasses such as Spartina patens (saltmeadow cordgrass), Distichlis spicata (salt or spike grass), and the stunted form of S. alterniflora appear to form the high marsh zone. The upper marsh zone, reached only by the highest spring tides, is characterized by, for example, Scirpus (sedge) species, Phragmites australis (reed), and Thypha (cattail) species. Depending on the influx of freshwater into the marsh, upper marsh plants can reach (much) lower into the tidal frame.

\section{WASHOVER DEPOSITS}

Donnelly et al. (2001a) discovered 6 overwash fans preserved in the stratigraphy of SM. They used (unspecified) plant fragments sieved from $0.5-1 \mathrm{~cm}^{3}$ of peat collected from the base of the sand layers (i.e. the very top of the underlying salt-marsh peat) for ${ }^{14} \mathrm{C}$ dating using accelerator mass spectrometry (AMS). Of these 6 fans, only the deepest/oldest two are of relevance here (fans VI and V). Two samples were obtained for the base of fan VI (the deepest) and 6 samples for the base of fan V, all from different cores. The ${ }^{14} \mathrm{C}$ ages were calibrated using the Calib 4.1 program (intercept method) of Stuiver et al. (1998). On the basis of mutual overlap of the calibrated $(2 \sigma)$ age ranges, Donnelly et al. (2001a) concluded that fan V was deposited between 1411 and 1446 cal AD (or between 1411 and $1433 \mathrm{cal} A D$ if the oldest of the 6 dates is excluded), and that the best estimate age range for the deposition of fan VI is 1295-1407 cal AD. At Whale Beach (WB), New Jersey, Donnelly et al. (2001b) bracketed the age of the only prehistoric overwash fan by AMS dating fragments of $S$. alterniflora collected from the topmost $\mathrm{cm}$ of the mud underlying the sand layer and from about $50 \mathrm{~cm}$ above the overwash deposit. The 2- $\sigma$ calibrated age ranges (Calib 4.1, probabilities method) indicate that this fan was deposited after $1278 \mathrm{cal} \mathrm{AD}$ and before $1434 \mathrm{cal} \mathrm{AD}$. This age range implies the possibility that the hurricane which deposited this sand layer, and which is inferred to have been very intense, was the same which produced fan VI at SM. However, it is not clear if the peat at the base of the sand layer at WB was eroded, and a meaningful analysis of synchroneity must await additional stratigraphic and ${ }^{14} \mathrm{C}$ data from the study area at WB. 


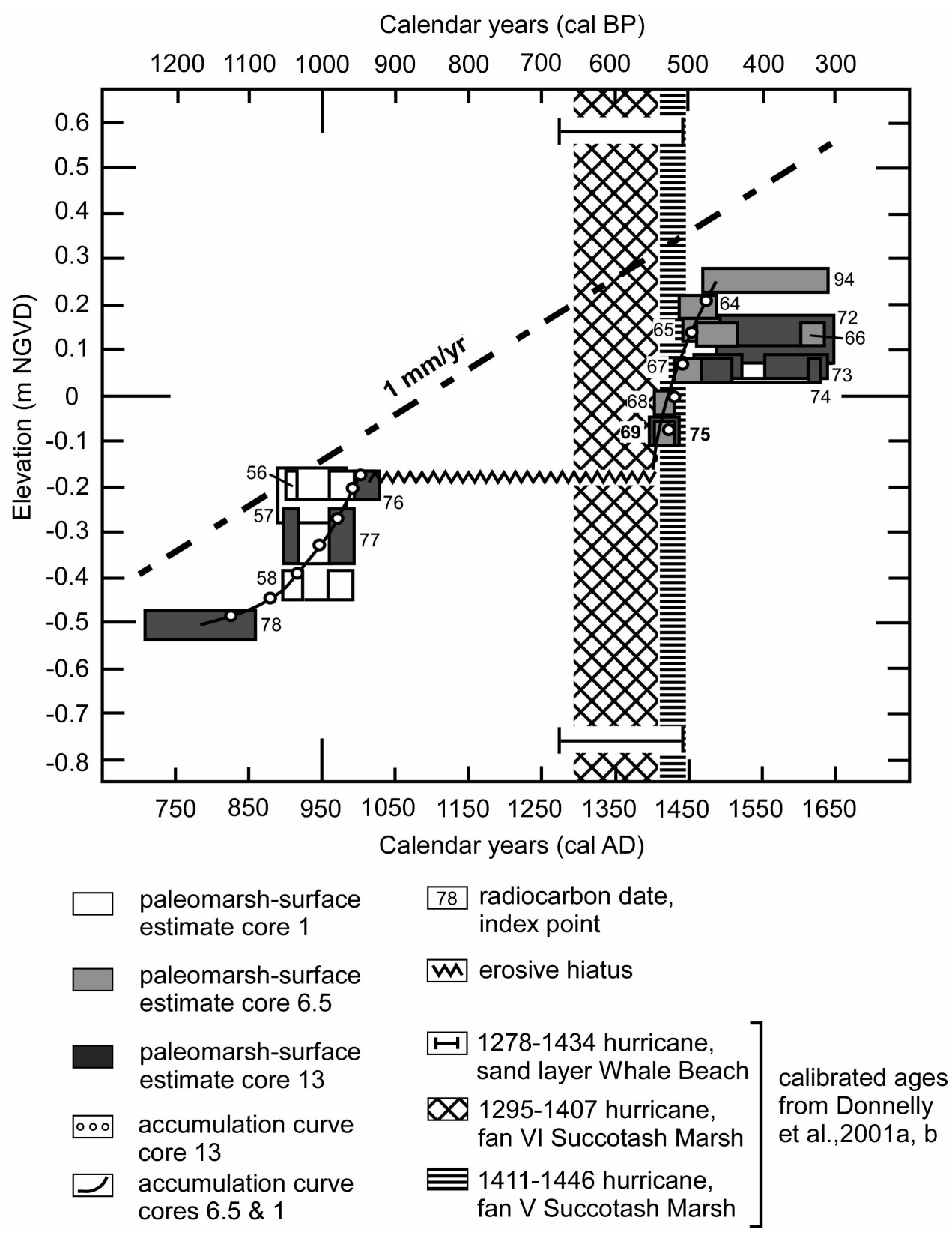

Figure 2 Comparison in time of an erosion-punctuated marsh-accumulation record from the study site at Hammock River Marsh, Connecticut (van de Plassche et al. 1998) with the occurrence of 2 geologically documented hurricanes in Succotash Marsh, Rhode Island, and one at Whale Beach, New Jersey (Donnelly et al. 2001a,b), indicating the possibility that a hurricane was responsible for the marsh erosion at Hammock River Marsh. The error boxes define the calibrated age and estimated elevation ranges of paleomarsh surfaces obtained by ${ }^{14} \mathrm{C}$ dating of paleomarsh-surface indicators (see text) collected from cores 1, 6.5, and 13 (for core locations and in-core position of dated samples, see Figures 1d and 3). 


\section{APPROACH AND METHODS}

Our approach is to first establish if a link between marsh erosion in HRM and hurricane activity recorded in SM is possible by determining visually the overlap of the best estimate in time (i.e. mutual overlap of calibrated age ranges) for hurricane activity in southern New England and New Jersey, as documented by Donnelly et al. (2001a,b), with that for the onset of first marsh growth following erosion in HRM. Given the result that such a link is possible, we then test its probability by (i) considering (theoretical) alternative explanations for marsh erosion; (ii) assessing available stratigraphical and sedimentological data from HRM in terms of time elapsed between the end of marsh erosion and the onset of recolonization by marsh plants; and (iii) presenting other data from Connecticut suggestive of a link between hurricane activity and marsh erosion.

Because of the very limited stratigraphic database available to van de Plassche et al. (1998) (Figure 3a), we revisited the study area at HRM to verify the presence or absence of erosive hiatuses. Using a 7.5 -cm-wide core auger, we reinspected the lithostratigraphy near and between cores $1,6.5$, and 13. The cores were split lengthwise and logged for color, sediment content, and plant macroremains. For the sake of comparability in time of overwash fan formation at WB and SM and of first post-erosion salt-marsh plant growth at HRM, we recalibrated the ${ }^{14} \mathrm{C}$ dates from these study sites using the INTCAL98 data set (Stuiver et al. 1998) and the OxCal program (probabilities method; Bronk Ramsey 1995).

\section{RESULTS}

\section{Stratigraphy}

In HRM, van de Plassche et al. (1998) found convincing evidence for erosion at a depth of about -0.20 m NGVD (National Geodetic Vertical Datum of 1929) in cores F and 13, and they interpreted the clear lower boundary of a thin bed of rooted clay in core 6.5 to be erosive as well (Figures $3 \mathrm{a}$ and $1 \mathrm{~d}$ ). The new stratigraphic information shows conclusively that the erosive boundary present at a depth of about $-0.20 \mathrm{~m}$ in cores $\mathrm{F}$ and 13 can be extended to several meters north of core 6.5 (Figure $3 \mathrm{~b}$ ). The accommodation space created by the erosion was filled in first by a thin $(5-10 \mathrm{~cm})$ bed of clayey silt to silty clay and, subsequently, by silty/clayey $S$. alterniflora peat (cores F and 13) and silty/clayey Sc. robustus peat with some D. spicata (core 6.5). The onset of post-erosion plant growth is approximated by the ages of index points 69 (core 6.5), 75 (core 13), and 83 (core F) (Figures 3b and 2; to avoid clogging, index point 83 is not shown in Figure 2, but it overlaps largely with index point 75). Previously, van de Plassche et al. (1998) overlooked the erosive boundary at the base of the body of sediment-rich Sc. robustus peat in core 6.5 because the basal sediment layer is crowded with sub-surface stems, root bulbs, and rhizomes of $S c$. robustus which first colonized it, and particularly because the sediment had been colored dark brown by humic substances lending the basal deposit the misleading appearance of a muddy $S c$. robustus peat conformably overlying high marsh peat.

The erosive nature of the base of the thin-rooted clay bed encountered in core 6.5 (at about $+0.24 \mathrm{~m}$ ) could not be confirmed. On the basis of the new stratigraphic data from the vicinity of core 6.5 , we now consider the sub-surface stem of Sc. robustus which gave index point 63 as belonging to the very top of the bed of $S c$. robustus peat. It appears that the thin clay layer previously observed in core 6.5 was deposited on the marsh surface without prior erosion.

In conclusion, the studied salt-marsh sequence at HRM contains only 1 unequivocal erosive boundary (Figure 3b). 


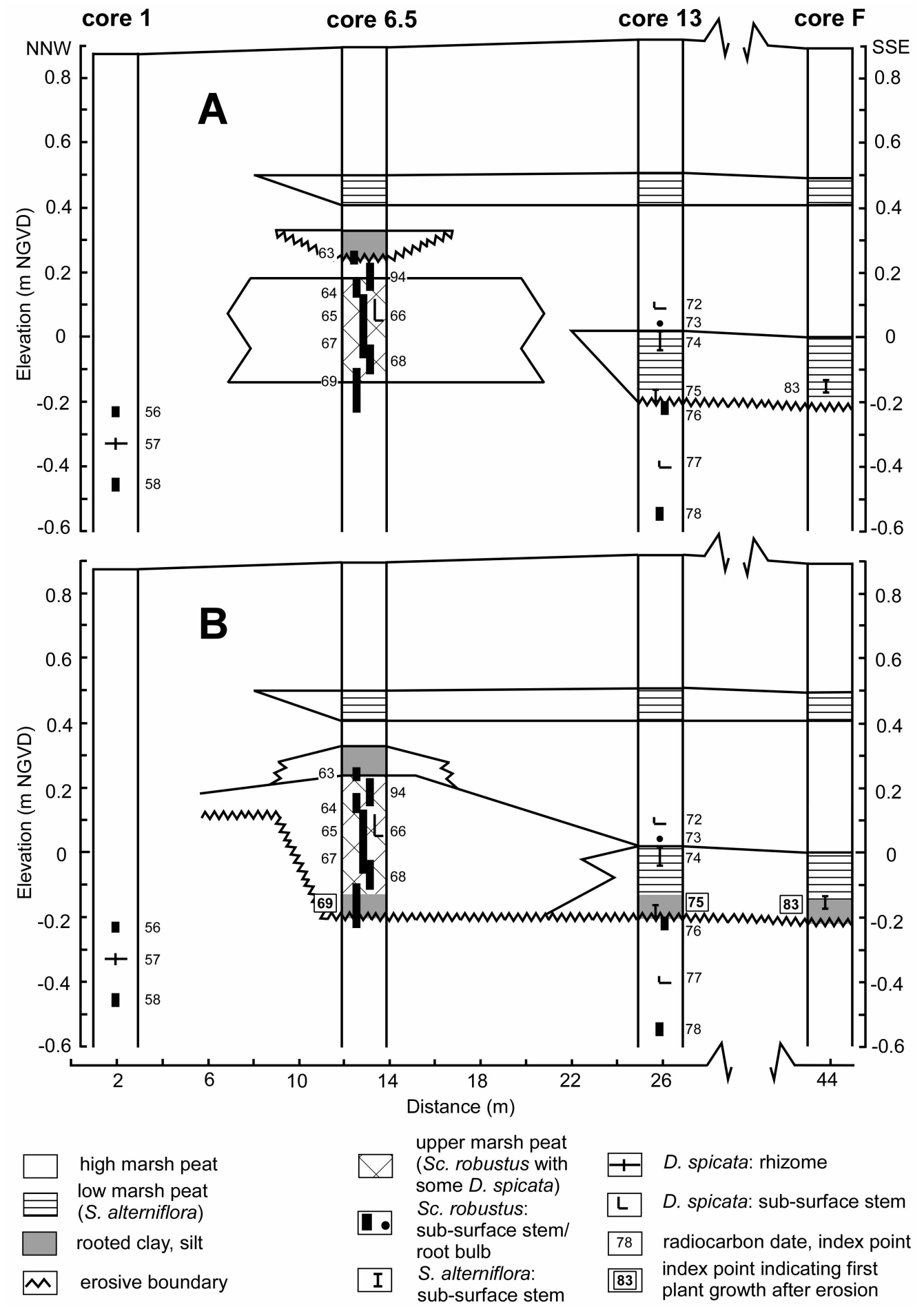

Figure 3 Simplified lithofacies distribution and original depth of $\left({ }^{14} \mathrm{C}\right.$-dated) samples in cores from the study site (A: previous [van de Plassche et al. 1998]; B: revised) showing that about $30 \mathrm{~cm}$ of high marsh peat was eroded over a distance of at least $34 \mathrm{~m}$ and replaced by sediment and silty/clayey low/upper marsh peat. 


\section{Age Calibration}

The recalibrated ages of the ${ }^{14} \mathrm{C}$ dates used in this paper are listed in Table 1. Donnelly et al. (2001a), using the intercept method for calibration, arrived at a best estimate (i.e. mutual overlap of calibrated age ranges at $2 \sigma$ ) for the time of deposition of fans VI and V at SM of 1295-1407 cal AD and 1411-1446 cal AD, respectively. The probabilities method yields almost the same best estimates (Figure 4). Minor differences exist also between our calibration result and that of Donnelly et al. (2001b) for the age (pre-)dating the overwash fan at WB (index point 11, Table 1).

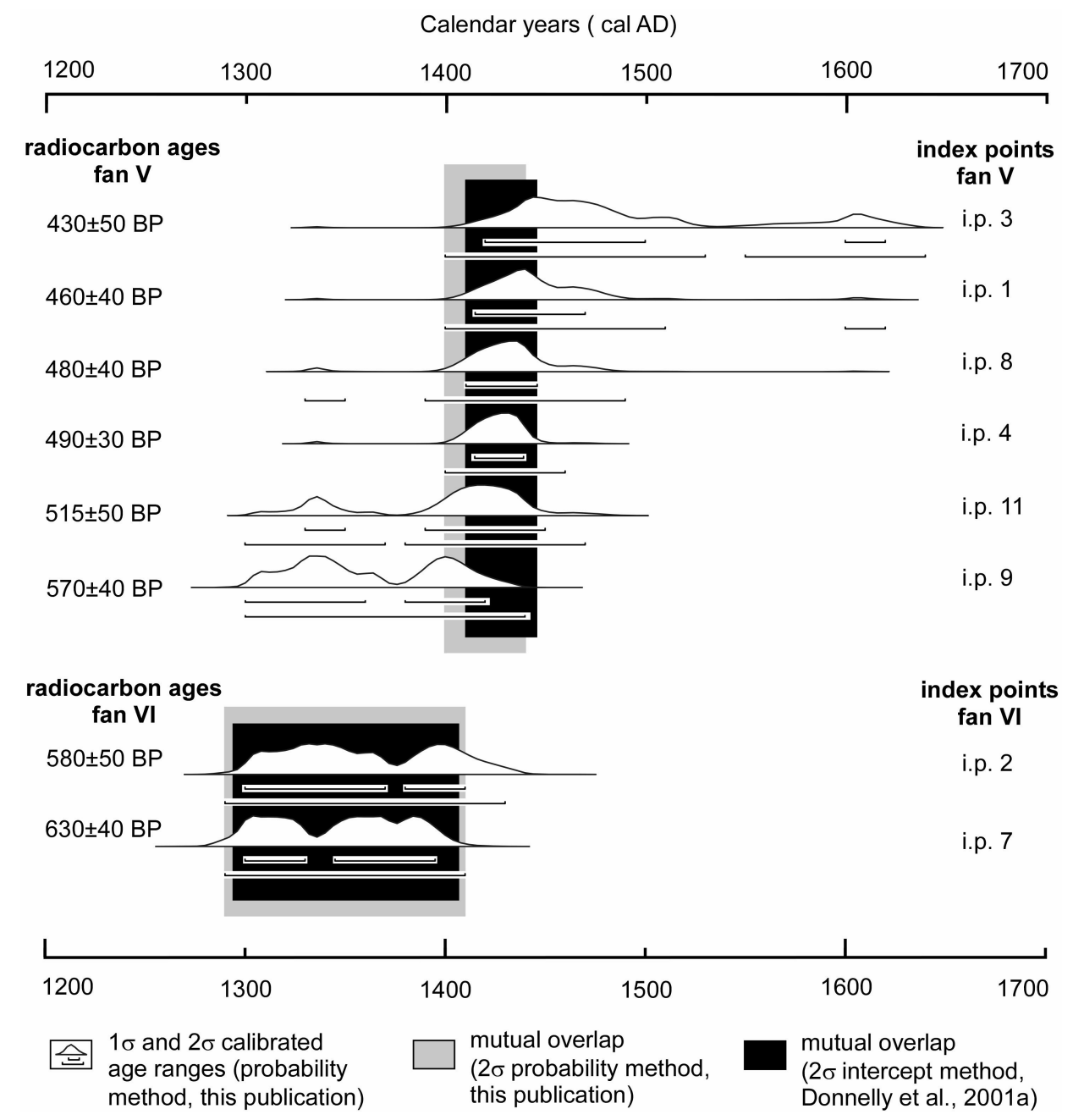

Figure 4 Comparison of best age estimates, based on mutual overlap of 1- $\sigma$ and of $2-\sigma$ calibrated age ranges, for the deposition of overwash fans VI and V at Succotash Marsh, Rhode Island, as obtained with the intercept and the probabilities method of calibration. 


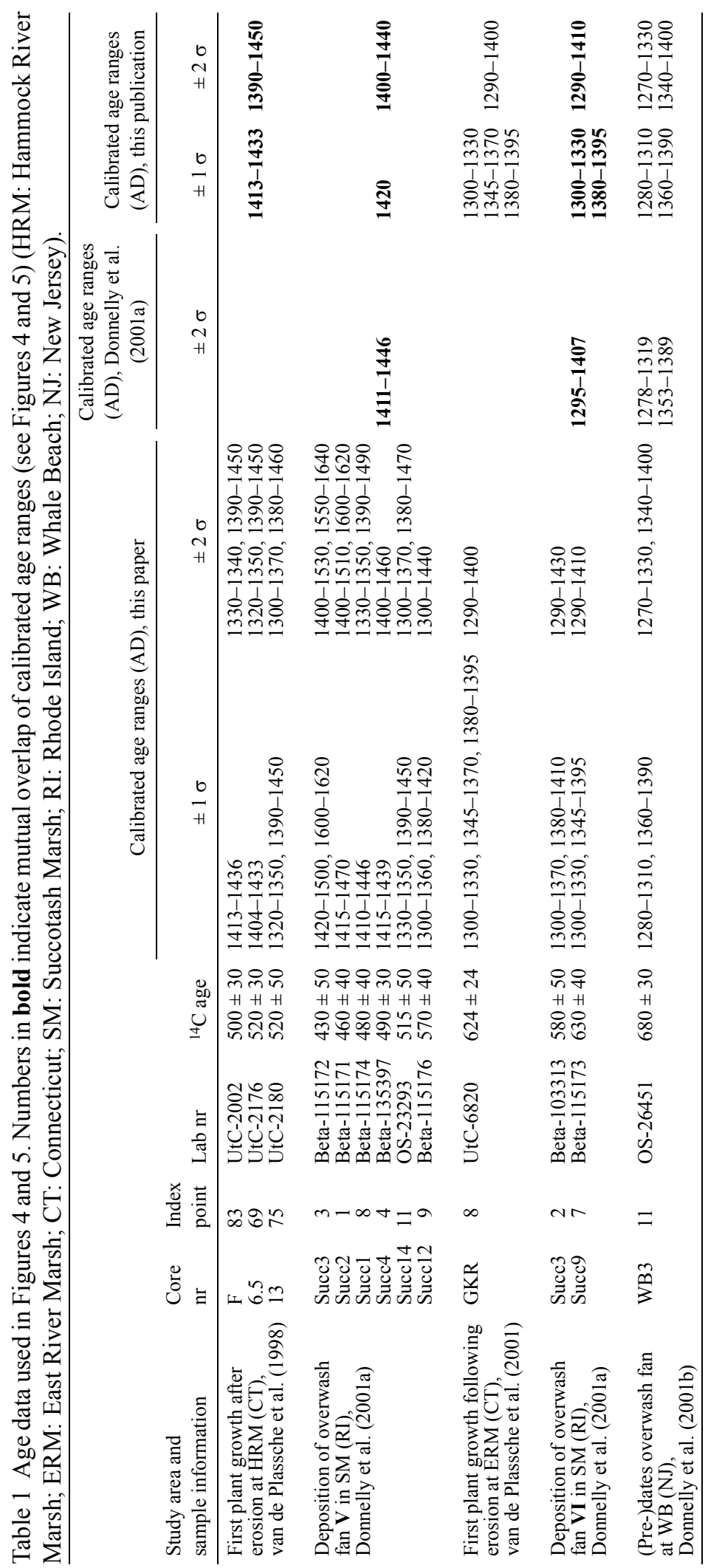




\section{Hurricane Deposition and Marsh Erosion in Time}

Comparison of the best estimate age range for the deposition of fan V at SM with that for first plant growth after erosion at HRM shows that the former falls entirely within the latter (Figure 5; Table 1), indicating a high probability that both events occurred close in time. In contrast, the best age estimates for fan VI and the fan at WB overlap just $12 \%$ and $6 \%$, respectively, with the best estimate for the onset of marsh growth after erosion at HRM (Figure 5, Table 1). If a hurricane was responsible for this erosion, it was, therefore, most likely the one that deposited fan V at SM.

\section{DISCUSSION AND CONCLUSIONS}

The complete overlap of the best age estimates for the onset of marsh recovery following erosion in HRM with that for the deposition of overwash fan $\mathrm{V}$ about $90 \mathrm{~km}$ to the east renders it possible that the 2 events are causally related. For the status of this linkage to be upgraded from possible to probable, it is necessary to show or argue that (i) the erosion was, most likely, caused or triggered by high-energy waves and currents, and (ii) little time elapsed between the end of marsh erosion and the recolonization of the site by marsh plants.

With respect to the first point, high-energy wave and current action can result from a hurricane or a tsunami triggered by a seismotectonic event. While minor earthquakes are common in southern New England, relative sea-level data from Connecticut demonstrate conclusively that no seismotectonic crustal movements have occurred during at least the past $3300 \mathrm{yr}$ (van de Plassche et al. 2002). Moreover, Long Island shields the coast of Connecticut from tsunami waves that may have originated off the Atlantic seaboard. Still, one or more of the following 3 other mechanisms, not involving hurricane conditions, may have caused the shallow erosion: (a) mechanical and/or biochemical saltpan and pond-hole formation, (b) headward erosion of a shallow tidal creek, and (c) lateral expansion of mudflat by marsh-cliff retreat. The absence of organic-rich mud, characteristic of pond-hole deposits, indicates that pond-hole formation is, by itself, not an option to explain the marsh erosion. The presence of shallow pond holes would have enhanced, however, the effectiveness of storm-wave and/or tidal erosion and little or no pond-hole deposit would have been preserved. As for headward erosion of a shallow tidal creek, this process reflects a gradual expansion of the drainage network in response to an increase in tidal prism or an increase in the rate of sea-level rise relative to the rate of marsh accumulation. It is difficult to explain why such a steady dynamic process would end abruptly and give way to rapid infilling of the shallow creek channel with sediment and low/upper marsh peat. Finally, marsh-cliff retreat caused by gradual undercutting would account for the sub-horizontal nature of the erosive boundary, but does not explain why the eroded surface, given its level of just 10-20 cm below local mean high water (Varekamp et al. 1992), was suddenly and simultaneously colonized by Sc. robustus (which requires brackish conditions) and S. alterniflora. We conclude that hurricane activity, by itself or in combination with pond holes, offers the simplest explanation for the marsh erosion and the subsequent synchronous recolonization by Sc. robustus (implying sufficient influx of fresh seepage water) and S. alterniflora of the thin layer of sediment deposited on the erosion surface. Mapping of the extent and configuration of the erosive surface over a significant area is likely to yield clues supporting or invalidating this interpretation.

With respect to the second point (rapid establishment of marsh plants following erosion), we infer from the freshness of the peat immediately below the erosive boundary and the absence of crab holes or molluscs in this peat that the erosion surface was not exposed for any length of time. These observations, combined with the fact that (a) the erosion lowered the marsh surface just about $30 \mathrm{~cm}$, i.e., just into the low marsh zone, (b) first plant growth in cores $6.5,13$, and 11 occurred simultaneously, and (c) the rate of subsequent marsh accumulation was very high, lead us to infer that little time elapsed between the erosion and first plant growth. 


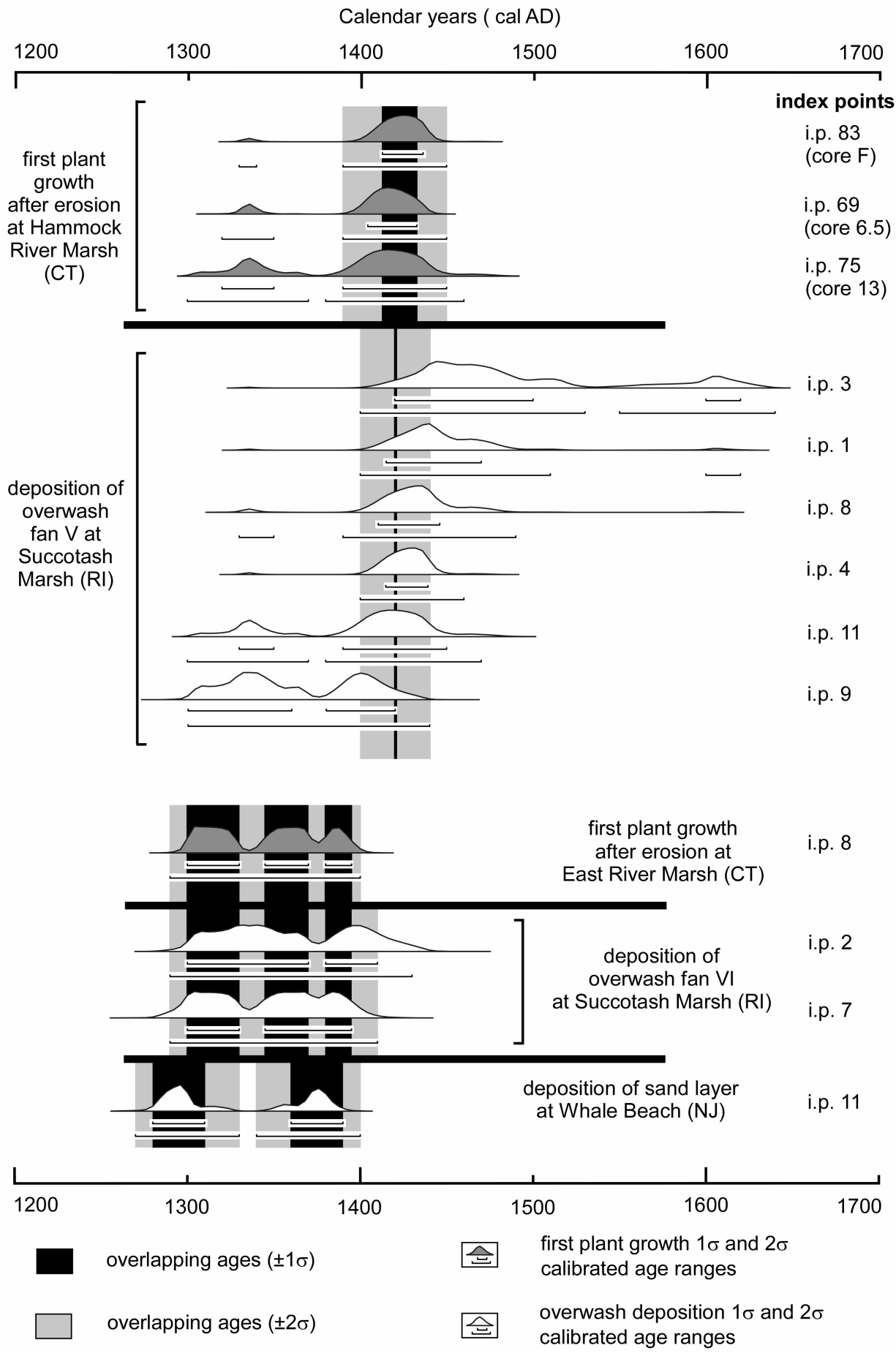

Figure 5 Comparison of best age estimates, based on visual mutual overlap of 1- $\sigma$ and of 2- $\sigma$ calibrated age ranges, for deposition of overwash fans VI and V at Succotash Marsh and the overwash fan at Whale Beach with those for first plant growth following marsh erosion in East River Marsh and Hammock River Marsh. (CT: Connecticut; RI: Rhode Island; NJ: New Jersey). 
From this evaluation, we conclude that it is plausible that the erosion at HRM is causally linked to the 15th century hurricane which deposited washover fan V at SM. Support for the concept of erosive boundaries in late Holocene salt-marsh deposits serving as paleotempest markers is found in stratigraphic and ${ }^{14} \mathrm{C}$ data from East River Marsh, located about $12 \mathrm{~km}$ west of HRM (Figure 1B) (Figure 4 in van de Plassche et al. 2001). Here, the calibrated ${ }^{14} \mathrm{C}$ age $(1290-1400$ cal AD; Table 1) for first plant growth following shallow marsh erosion to a depth of $0.98 \mathrm{~m}$ below the marsh surface overlaps for $91 \%$ with the best age estimate for deposition of overwash fan VI at SM. (Figure 5). In the same core from East River Marsh, the wiggle-matched age (1680 cal AD; van de Plassche et al. 2001 ) for first plant growth after shallow marsh-surface erosion to a depth of about $0.75 \mathrm{~m}$ below the marsh surface implies the possibility that the erosion was linked to the historically documented category 2 hurricane of AD 1675 (Boose et al. 2001).

In conclusion, the pre-historical record of hurricane strikes on the southern New England coast is currently based on sedimentary evidence (overwash deposits) only. The data and analysis presented here show that erosive boundaries in salt-marsh deposits deserve attention as potential paleotempest indicators. However, diagnostic criteria to distinguish storm erosion from non-storm erosion need to be defined if this marker is to be used to its full potential. In the absence of such criteria, synchronous first plant growth following erosion in several marshes located many kilometers apart will strengthen the case for hurricane-related erosion.

\section{ACKNOWLEDGEMENTS}

We thank Jaap Erkelens and Kim van der Leeuw for field assistance and an anonymous reviewer for thoughtful comments.

\section{REFERENCES}

Bertness MD. 1991. Zonation of Spartina patens and Spartina alterniflora in a New England salt marsh. Ecology 72:138-48.

Boose ER, Chamberlin KE, Foster DR. 2001. Landscape and regional impacts of hurricanes in New England. Ecological Monographs 71(1):27-48.

Bronk Ramsey C. 1995. Radiocarbon calibration and analysis of stratigraphy: the OxCal program. Radiocarbon 37(2):425-30.

Donnelly JP, Bryant SM, Butler J, Dowling J, Fan L, Hausmann N, Newby P, Shuman B, Stern J, Westover K, Webb III T. 2001a. 700 yr sedimentary record of intense hurricane landfalls in southern New England. Geological Society of America Bulletin 113(6):714 27.

Donnelly JP, Roll S, Wengren M, Butler J, Lederer R, Webb III T. 2001b. Sedimentary evidence of intense hurricane strikes from New Jersey. Geology 29(7): 615-8.

Niering WA, Warren RS. 1980. Vegetation patterns and processes in New England salt marshes. Bioscience 30:301-7.

Nyman JA, Crozier CR, Delaune RD. 1995. Roles and patterns of hurricane sedimentation in an estuarine marsh landscape. Estuarine Coastal and Shelf Science 40:665-79.

Stuiver M, Reimer PJ, Bard E, Beck JW, Burr GS, Hughen KA, Kromer B, McCormac FG, van der Plicht J, Spurk M. 1998. INTCAL98 radiocarbon age calibration: 24,000-0 BP. Radiocarbon 40(3):1041-83.

van de Plassche O, van der Borg K, de Jong AFM. 1998. Sea level-climate correlation during the past $1400 \mathrm{yr}$. Geology 26:319-22.

van de Plassche O, van der Borg K, de Jong AFM. 2002. Relative sea-level rise across the Eastern Border fault (Branford, Connecticut): evidence against seismotectonic movements. Marine Geology 184:61-8.

van de Plassche O, Edwards RJ, van der Borg K, de Jong AFM. 2001. ${ }^{14} \mathrm{C}$ wiggle-match dating in high-resolution sea-level research. Radiocarbon 43(2A):391402.

Varekamp JC, Thomas E, van de Plassche O. 1992. Relative sea-level rise and climate change over the last 1500 years (Clinton, CT, USA). Terra Nova 4: 293-304.

Warren RS, Niering WA 1993. Vegetation change on a northeast tidal marsh: interaction of sea-level rise and marsh accretion. Ecology 74:96-103. 